\title{
Hydrogen Amount Estimation in Electrodes of Nickel-Cadmium Batteries Depending on Their Operating Life
}

\author{
Nataliya N. Yazvinskaya ${ }^{1}$, Nikolay E. Galushkin ${ }^{1,}$, Dmitriy N. Galushkin ${ }^{1}$, Inna A. Galushkina ${ }^{2}$ \\ ${ }^{1}$ Don State Technical University, Laboratory of electrochemical and hydrogen energy, 147 \\ Shevchenko Street, Town of Shakhty, Rostov Region, Russia, 346500. \\ ${ }^{2}$ Southern Federal University, Novoshakhtinsk branch, 2 Oktiabria Street, Town of \\ Novoshakhtinsk, Rostov Region, Russia, 346900. \\ *E-mail: galushkinne@mail.ru
}

doi: $10.20964 / 2016.09 .49$

Received: 7 June 2016 / Accepted: 15 July 2016 / Published: 7 August 2016

In this investigation, it was shown that hydrogen is absent in the electrodes of new nickel-cadmium batteries. However, during batteries operation, a lot of hydrogen is accumulated in their electrodes. The amount of hydrogen accumulated by the electrodes stops increasing after five years of service life.

Keywords: Hydrogen accumulation, battery, nickel-cadmium, thermal runaway

\section{FULL TEXT}

(C) 2016 The Authors. Published by ESG (www.electrochemsci.org). This article is an open access article distributed under the terms and conditions of the Creative Commons Attribution license (http://creativecommons.org/licenses/by/4.0/). 